\title{
TRADISI JEULAMEE DI PASEE BAGIAN UTARA: KAJIAN ANTROPOLOGI BUDAYA DI KECAMATAN DEWANTARA KABUPATEN ACEH UTARA
}

\author{
Habsatul Murniyati ${ }^{1}$, Teuku Kemal Fasya ${ }^{1}$ \\ 1 Program Studi Antropologi, Fakultas Ilmu Sosial dan Ilmu Politik \\ Universitas Malikussaleh
}

Korespondesi: habsatulmurniyati@gmail.com

\begin{abstract}
Abstrak: Penelitian ini berjudul "Tradisi Jeulamee Di Pasee Utara (Kajian Atropologi Budaya Di Kecamatan Dewantara Kabupaten Aceh Utara). Adapun rumusan masalah pada penelitian ini adalah bagaimana bentuk tradisi jeulamee di wilayah Pasee Utara, seperti apakah perbedaan tradisi jeulamee di Pasee Utara dengan tradisi jeulamee di wilayah lainnya dan apakah terdapat gensi dengan memperbesar jeulamee di Pasee Utara. Tujuan dalam penelitian ini untuk mengetahui dan mendeskripsikan tentang tradisi jeulamee di Pasee Utara, untu mengetahui dan mendeskripsikan perbedaan tradisi jeulamee dengan tradisi di wilayah lainnya serta mengetahui dan mendeskripsikan sejauh mana gensi dengan memperbesar jeunamee di Pasee Utara. Metode yang digunakan dalam penelitian ini adalah menggambarkan kajian tentang antropologi budaya. Sumber data dalam penelitian terdiri dari data primer dan sekunder. Teknik pengumpulan data yang digunakan adalah observasi, wawancara dan dokumentasi. Hasil penelitian menunjukkan bahwa pemahaman masyarakat di wilayah Pasee Utara tentang tradisi jeulamee yaitu masyarakat setempat menerima dengan kebiasaan atau tradisi yang telah menjadi adat orang Aceh dari zaman dahulu sampai dengan sekarang, sehingga tradisi tersebut tidak dapat dihilangkan dan sudah menjadi budaya bagi masyarakat Gampong Paloh Lada. Perbedaan tradisi jeulamee di Pasee Utara dengan tradisi jeulamee di wilayah Pasee lainnya yaitu penetapan mahar mas kawin (jeunamee) ditentukan oleh kedua belah pihak tanpa memberatkan bagi pihak lelaki, namun bagi keluarga yang mempunyai kehidupan sosial yang tinggi, maka penetapan jeunamee ditentukan oleh keluarga pihak perempuan. Upaya dalam mempertinggi jeulamee wilayah Pasee Utara dijadikan sebagai salah satu adat yang telah diwariskan turun temurun dalam menjaga ikatan dan solidaritas yang kuat di masyarakat, sehingga derajat wanita dalam sosial masyarakat tidak diremehkan, namun bagi keluarga perempuan yang status sosialnya sederhana, maka jeulamee yang diminta tidak memberatkan pihak kaum lelaki yang melamarnya.
\end{abstract}

Kata Kunci: Tradisi Jeulamee, Perbedaan Jeulamee, Gengsi 


\section{A. Pendahuluan}

Tradisi mahar emas dalam tradisi Islam menjadi sebuah keharusan bagi seorang mempelai pria, yang telah diminta oleh calon mempelai wanita, dengan adanya tradisi tersebut mempelai pria harus berusaha memenuhi emas. Walaupun mempelai pria berasal dari keluarga tidak mampu, sanak saudara dari mempelai pria akan tetap membantu menyumbang demi berlangsungnya pernikahan antara mempelai pria dari wanita. Tidak banyak dari para mempelai pria yang mudahnya melangsungkan pernikahan ini. Ada sebagian dari mereka yang harus bekerja terlebih dahulu untuk mengumpulkan emas, sehingga pernikahannya ditunda beberapa bulan atau tahun sampai dia mampu mengumpulkan emas tersebut (Yunus \& Mahmud, $2013: 78$ ).

Hadikusuma dan Hilman (2005 : 14) menyatakan bahwa tradisi perkawinan yang terdapat dalam suatu daerah pada umumnya berbeda-beda, akad nikah (ijab dan kabul) yang dilangsungkan adalah menjadi kewajiban mempelai pria untuk memberikan mahar (mas kawin) kepada mempelai wanita. Mahar yang diberikan dapat berupa uang, barang (harta benda) maupun dalam bentuk jasa. Dengan mendasar pada ketentuan-ketentuan tersebut di atas, maka pemberian mahar oleh suami kepada isterinya merupakan suatu kewajiban. Pernikahan dalam Islam pada dasarnya tidak memberatkan mempelai, akan tetapi dengan adanya tradisi seperti ini yang melekat dan sudah turun temurun dan masih bertahan sampai sekarang. Walaupun tradisi tersebut merupakan beban bagi mempelai pria, namun mereka semua sadar bahwa setiap makhluk diciptakan dengan cara berpasang-pasangan.

Salah satu budaya yang ada di Indonesia adalah upacara adat perkawinan yang merupakan warisan nenek moyang dan di dalamnya terdapat aturan-aturan tata pelaksanaan adat yang telah diatur dalam tata krama adat sesuai daerah masing-masing. Upacara perkawinan adalah hal yang paling kuat dalam mengikat hidup kelompok manusia. Aceh merupakan salah satu daerah di Indonesia yang masyarakatnya bersifat multi etnis Arab, China dan Hindia. Di daerah ini terdapat delapan sub etnis yaitu Aceh Alas, Aneuk Jamee, Gayo, Kluet, Simeulu, Singkil dan Tamiang. Kedelapan sub etnis tersebut mempunyai sejarah budaya yang berbedabeda, termasuk juga pada adat perkawinannya. Upacara perkawinan pada masyarakat Aceh merupakan sesuatu yang sangat sakral, sebab hal ini berhubungan 
dengan nilai-nilai keagamaan. Upacara perkawinan pada masyarakat Aceh merupakan serangkaian aktivitas yang terdiri dari beberapa peresmian perkawinan yang dapat dijadikan sebagai tradisi perkawinan termasuk di wilayah Aceh Utara.

Pernikahan diselenggarakan dalam sebuah prosesi khusus dengan tata cara yang khusus yang disesuaikan dengan ketentuan dalam agama maupun dalam tradisi masyarakat dimana prosesi itu akan dilaksanakan. Terkhusus ketentuan dalam agama Islam, terdapat beberapa hal yang menjadi rukun dan syarat dalam pernikahan. Rukun dan syarat ini sama-sama harus dipenuhi, baik proses sebelum akad nikah maupun pada saat pelaksanaan akad nikah. Dalam hal ini adanya kedua mempelai adalah yang terpenting dari syarat dan rukun pernikahan. Adanya kedua mempelai merupakan hal primer baik sebelum maupun pada saat pelaksanaan pernikahan, karena keduanyalah yang akan menjalani pernikahan.

Mahar merupakan hal yang paling penting dalam pernikahan. Mahar dalam Bahasa Arab adalah shadaq dari kata kerja ashadaqa (Abidin, dkk, 2009 : 105). Dinamakan shadaq karena memberikan arti benar-benar cinta nikah dan inilah yang menjadi pokok kewajiban mahar atau mas kawin. Secara etimologi mahar juga berarti mas kawin. Adapun pengertian mahar menurut istilah Ilmu Fiqih adalah pemberian wajib dari calon suami kepada calon istri sebagai ketulusan hati calon suami, untuk menimbulkan rasa cinta kasih bagi seorang istri kepada calon suaminya (Abidin, dkk, 2009 : 105).

Agama dan adat budaya sangat memperhatikan dan menghargai kedudukan seorang wanita dengan memberi hak kepadanya di antaranya adalah hak untuk menerima mahar. Mahar hanya diberikan oleh calon suami kepada calon istri, bukan kepada wanita lainnya atau siapapun, walaupun sangat dekat dengannya. Orang lain tidak boleh menjamah apalagi menggunakannya meskipun oleh suaminya sendiri, kecuali dengan rida dan kerelaan istri. Sejak zaman pra Islam telah ada berbagai macam corak perkawinan, mulai dari perkawinan patrilinear dan patrilokal, matrilinear dan matrilokal, hingga perkawinan temporer untuk sekedar bersenangsenang perkawinan (perkawinan mut'ah). Bentuk perkawinan yang terhormat di masa itu, yaitu perkawinan patrilinear, dimana pengantin pria membayar sejumlah uang (mahar) kepada calon pengantin wanitanya (Ilham, $2010: 64$ ). 
Dalam perkembangan berikutnya, mahar berkembang menjadi alat yang dibayarkan kepada keluarga pengantin wanita sebagai imbalan atas hilangnya fungsi ekonomi calon istri dan sebagai sarana untuk menciptakan kestabilan ikatan dan hubungan antara kedua keluarga yang saling bermenantu. Mahar merupakan salah satu ciri khas hukum perkawinan, paralel dengan permasalahan wali, pemberian mahar pada masa dulunya sangat berkaitan dengan kondisi perempuan yang tidak memiliki hak dan kebebasan, sehingga pemberian mahar dengan sendirinya diperuntukkan bagi wali si perempuan, sebagai kompensasi karena ia sudah membesarkannya dan resiko akan kehilangan peran yang dimainkan anak nantinya di rumah bapaknya. Hal ini yang menyebabkan mahar ditafsirkan sebagai harga beli seorang perempuan dari walinya. Berdasarkan latar belakang di atas maka peneliti tertarik untuk melakukan penelitian dengan mengangkat judul : Tradisi Jeulamee Di Pasee Utara (Kajian Atropologi Budaya Di Kecamatan Dewantara Kabupaten Aceh Utara).

\section{B. Metode Penelitian}

Dalam penelitian ini peneliti pendekatan yang digunakan dalam penelitian ini adalah pendekatan antropologi budaya yang mempelajari tentang perilaku atau tingkah laku manusia sehari-hari, baik itu perilaku individu maupun kelompok, dimana data yang digunakan berasal dari pengalaman individu masyarakat dan pengalaman individu tersebut nanti akan digunakan untuk menggambarkan keadaan masyarakat yang diteliti terutama yang berkenaan dengan permasalahan penelitian.

Orang-orang yang ditetapkan sebagai informan dalam penelitian ini adalah pihak-pihak yang bisa memberikan informasi mengenai tradisi mahar dan penetapan mahar di wilayah Pasee Utara Kecamatan Dewantara Kabupaten Aceh Utara. Adapun yang menjadi informan dalam penelitian ini yaitu pihak yang menikah, wali penikah, keluarga, saksi, tokoh masyarakat seperti Geuchik, Sekretaris Desa, Ketua Pemuda maupun masyarakat. Teknik pengumpulan datanya dengan melakukan observasi, wawancara, dokumentasi, studi literatur. Setelah itu teknik analisis data dengan melakukan reduksi data, penyajian data serta penarikan kesimpulan. 


\section{Pembahasan}

\section{Pemahaman masyarakat Kecamatan Dewantara Kabupaten Aceh Utara tentang Tradisi Jeulamee}

Perkawinan menurut hukum Islam merupakan pernikahan yaitu akad yang sangat kuat untuk mentaati perintah Allah dan melaksanakannya merupakan ibadah. Perkawinan merupakan fitrah yang dianugrahkan pada setiap manusia sejak zaman azali, yaitu ketika diciptakannya Nabi Adam dengan istrinya Siti Hawa. Perkawinan bukan hanya saja dambaan bagi setiap insan, tetapi merupakan naluri atau tabiat bagi setiap manusia. Melalui perkawinan, Allah SWT mengkaruniakan kepada manusia rasa cinta, kasih dan sayang diantara suami dan istri.

Mahar merupakan hak murni perempuan yang disyaria'tkan untuk diberikan kepada perempuan sebagai ungkapan keinginan pria terhadap perempuan tersebut, sebagai salah satu tanda kasih sayang calon suami terhadap calon istri dan suatu pemberian wajib sebagai bentuk penghargaan calon suami kepada calon istri yang dilamar, serta sebagai simbol untuk memuliakan, menghormati dan membahagiakan perempuan yang akan menjadi istrinya. Adanya kewajiban memberikan mahar kepada istri, terbentanglah tanggung jawab yang besar dari suami untuk memberikan nafkah di dalam kehidupan rumah tangga secara layak. Hal ini sesuai dengan pernyataan yang dikemukakan oleh Bapak Husaini selaku saksi di Gampong Paloh Lada Kecamatan Dewantara yang menyatakan bahwa :

"Penetapan mahar di desa ini tergantung kepada orang tua ataupun sang anak sendiri. Kebanyakan penetapan tradisi jeulamee sekarang terlihat lebih banyak dari pada orang-orang terdahulu. sekarang paling rendah 10 mayam dan paling banyak 35 mayam, itu pun terlihat dari keluarga yang kaya, namun ada juga bagi sebahagian orang yang keadaannya sederhana jeulamee yang ditetapkan tinggi" (Wawancara, 23/01/2017).

\section{Perbedaan Tradisi Jeulamee di Pasee Utara dengan tradisi Jeulamee di wilayah Pasee lainnya}

Salah satu budaya yang ada di Kecamatan Dewantara adalah mengikuti adat perkawinan yang merupakan warisan nenek moyang yang di dalamnya terdapat aturan-aturan tata pelaksanaan adat yang telah diatur dalam tata krama adat sesuai daerah masing-masing. Dalam perkawinan banyak hal yang harus diperhatikan, 
antara lain adalah mahar, karena salah satu hubungan hukum yang timbul dari sebab perkawinan adalah kewajiban calon suami untuk memberi mahar.

Mahar yang diberikan kepada seorang istri merupakan kewajiban yang harus dipenuhi oleh seorang suami yang akan melangsungkan pernikahan. Menurut hukum perkawinan dalam Islam, suatu perkawinan dapat dilakukan walaupun tanpa menentukan kadar mahar ataupun menyebutnya dalam 'aqad. Dengan demikian jelaslah bahwa perkawinan yang berlangsung tanpa menyebutkan mahar menimbulkan beberapa alternatif yaitu mahar tersebut akan diperlakukan jika telah terjadi hubungan suami istri.

Mahar yang penulis maksudkan dalam pembahasan skripsi ini adalah mas kawin (jeulamee) berupa harta pemberian dari mempelai laki-laki kepada mempelai wanita yang merupakan hak istri dan disebutkan ketika 'aqad berlangsung. Sebagaimana Bapak Drs Boihakki selaku kepala KUA Kecamatan Dewantara menjelaskan bahwa :

"setiap wanita yang dinikahi wajib diberikan mahar (Jeulamee). Namun mahar tersebut bervariasi dengan kesepakatan dari kedua belah pihak, sehingga dalam akad nikah disebutkan maharnya dengan jelas karena nantinya jumlah mahar tersebut tertulis dalam dokumen atau buku nikah yang telah diucapkan pada saat akad nikah. Pada saat akad nikah mahar tersebut harus disebutkan berapa jumlahnya agar lebih afdal, karena itu merupakan hak si perempuan yang harus diberikan oleh laki-laki, sehingga harus disebutkan meskipun jumlah mahar hanya 1 mayam, karena itu juga kewajiban laki-laki untuk menghargai dan memuliakan wanita yang bakalan menjadi istrinya" (Wawancara, 23/01/2017).

Wujud dari suatu mas kawin bukan hanya untuk menghargai atau menilai perempuan saja, melainkan sebagai bukti bahwa calon suami sebenarnya cinta kepada calon istrinya, sehingga dengan suka rela hati ia mengorbankan hartanya untuk diserahkan kepada istrinya, sebagai tanda suci hati dan sebagai pendahuluan, bahwa sang suami akan terus-menerus memberi nafkah kepada istrinya sebagai suatu kewajiban suami terhadap istrinya.

Hikmah pewajiban mahar bagi istri atas suami ialah menunjukkan dan mengangkat tinggi kepentingan hubungan ini. Pewajiban mahar atas suami secara khusus, dimana suami yang lebih mampu untuk bekerja dan memberi nafkah, mengandung isyarat kepada apa yang diwajibkan oleh perkawinan atas suami, 
berupa berbagai tuntutan kebutuhan dan nafkah. Mahar mengandung suatu penghormatan kepada wanita yang masuk dalam ketaatan kepadanya dan dalam perlindungannya.

Ketentuan mahar yang tidak kaku dalam Islam mengindikasikan bahwa mahar bukan merupakan harga mutlak yang tidak bisa ditawar dalam pengertian membeli, tetapi lebih sebagai simbol dari penghargaan terhadap perempuan yang tidak bisa dinilai secara material. Simbol ini mengawali bagaimana kelak dalam kehidupan keluarga, perempuan bukan merupakan hak properti laki-laki, tetapi justru memiliki hak properti yang bebas ia pergunakan untuk kepentingannya sendiri. Oleh karena itu, nilai substansi dari mahar adalah menghargai perempuan, pertanda hak kepemilikan dan independensi ekonomi perempuan.

Gengsi dengan memperbesar Jeulamee di Wilayah Pasee Utara

Dalam hukum Islam mengajarkan bahwa mahar tidak memiliki ukuran batas yang harus dilakukan dan tidak boleh melebihinya. Ukuran mahar diserahkan kepada kemampuan suami sesuai dengan pandangannya yang sesuai. Tidak ada dalam peraturan yang membatasi mahar sampai tinggi dan tidak boleh melebihinya.

Dalam sebuah pernikahan ketentuan mahar tidak ada batas minimal dalam mahar, tetapi segala sesuatu yang dinilai material patut menjadi mahar. Sesuatu yang layak dijadikan mahar adalah seperempat dinar emas atau tiga dirham perak. Artinya, harta seukuran itu mempunyai arti nilai dan kehormatan berdasarkan dipotong tangan pencurinya dan tidak dipotong di bawah ukuran itu, maka itulah batas ukuran minimal mahar (Faridl dan Miftah, 2009 : 73).

Adanya pernikahan menjadi sebab seorang suami diwajibkan memberikan sesuatu kepada isterinya baik berwujud uang maupun berupa barang. Pemberian ini disebut mahar. Mahar adalah sesuatu yang wajib ada meskipun tidak dijelaskan bentuk dan harganya pada saat akad nikah namun pada kenyataannya yang terjadi ditengah-tengah masyarakat masalah mahar tetap disebutkan pada waktu akad nikah menurut ukuran yang pantas.

Kenyataan bahwa manusia itu berbeda-beda tingkat ekonominya, sehingga sangat bisa dipahami bahwa sebagian dari manusia ada yang kaya dan sebagian besar miskin. Ada orang mempunyai harta melebihi kebutuhan hidupnya, namun sebaliknya ada juga yang tidak mampu memenuhinya. Oleh karena itu, Islam 
memberikan keringanan kepada laki-laki yang tidak mampu memberikan mahar bernilai nominal yang tinggi sesuai permintaan calon istri untuk dapat mencicilnya atau mengangsurnya. Kebijakan ini sebagai jalan tengah agar dapat solusi terbaik antara kemampuan suami dan hak istri supaya tidak ada yang merasa dirugikan.

Perkawinan dalam masyarakat Paloh Lada ditandai dengan dimulainya jalinan hubungan berdasarkan cinta kasih yang sah menurut adat dan agama yang kemudian diikuti oleh tradisi Jeulamee yang biasa dilakukan. Perkawinan dalam masyarakat dapat diartikan bukan hanya sebagai menyatukan dua orang menjadi sepasang suami istri, tetapi juga menyatukan dua rumpun keluarga yang lebih besar yaitu keluarga dari pihak mempelai laki-laki dan keluarga dari pihak mempelai wanita.

Di Pasee bagian Utara ini nilai mahar mas kawin yang diberikan pada seorang wanita berbeda-beda dengan wilayah Pasee lainnya. Hal ini dapat dilihat berdasarkan jenjang pendidikan yang tinggi atau tingkat status perempuan yang masih gadis, justru nilai mahar yang diberikan lebih tinggi dibandingkan dengan jenjang pendidikan yang masih rendah atau berstatus janda. Meskipun kehidupan sang wanita dalam keadaan yang sederhana, namun dengan jenjang pendidikan yang tinggi ia dapat mempertahankan harga dirinya sebagai wanita di mata masyarakat, terlebih pada wanita yang masih gadis yang belum pernah menikah sekalipun, bahkan bagi wanita yang sudah mempunyai pekerjaan yang tetap, nilai mahar mas kawin yang diminta tidak kurang dari 13 mayam. Kecuali dengan status nya yang sudah janda dan berumur, tentu nilai mahar yang diminta tidak lebih dari 5 mayam, apalagi dengan keadaannya yang serba sederhana dan sudah memiliki anak dari perkawinan pertamanya.

Bagi kaum laki-laki makruh baginya memberi suatu mas kawin kepada istrinya dengan pembayaran yang menyusahkannya, atau sulit untuk dilunasi jika itu berupa pinjaman. Namun dalam pelaksanaan pembayaran, mahar ini juga tidak bisa dipaksakan dengan kekerasan. Islam mewajibkan mas kawin dan memastikannya, untuk dimiliki sang wanita sebagai kewajiban dari lelaki kepadanya yang tidak boleh ditentang. Islam mewajibkan sang suami memberikan mas kawin sebagai pemberian yang khusus kepada si wanita dan harus dengan hati yang tulus dan lapang dada, sehingga tidak ada paksaan bagi kaum lelaki yang akan 
menikahinya. Dengan adanya cara seperti ini, sehingga wanita dapat mempertahankan hak nya terhadap dirinya, kehormatan, kedudukannya, memberikan keleluasaan kepada sang wanita, saling merelakan dan kasih sayang untuk mewarnai kehidupan bersama serta untuk menyegarkan suasana kehidupannya.

Dalam hal ini dapat dijelaskan bahwa proses pernikahan diawali dari pihak yang menentukan nilai mahar pertama kali yaitu si lelaki dan perempuan. Pada saat lamaran, pihak dari lelaki dengan pihak perempuan bersepakat dengan keputusan terkait tentang seberapa besar mahar yang telah ditentukan sebelumnya. Meskipun sulitnya mengumpulkan sejumlah mahar yang ditentukan, namun pihak lelaki mesti berusaha dikarenakan Jeulamee atau mahar mas kawin sudah menjadi kewajiban yang diberikan pada saat akad nikah, maka pihak lelaki tidak keberatan dengan tradisi yang dijalankan ini.

Berdasarkan hasil observasi yang telah dikemukakan di atas, terlihat bahwa tradisi mahar Jeulamee merupakan adat yang masih dipertahankan dalam masyarakat Gampong Paloh Lada pada proses lamaran perkawinan. Upaya dalam mempertinggi Jeulamee wilayah Pasee Utara dijadikan sebagai salah satu tradisi dan telah menjadi tolak ukur yang telah diwariskan turun temurun dalam menjaga ikatan dan solidaritas yang kuat di masyarakat.

\section{Kesimpulan}

Adapun kesimpulan dari hasil penelitian di atas adalah sebagai berikut :

1. Pemahaman masyarakat di wilayah Pasee Utara tentang tradisi jeulamee yaitu masyarakat setempat menerima dengan kebiasaan atau tradisi yang telah menjadi adat orang Aceh dari zaman dahulu sampai dengan sekarang, sehingga tradisi tersebut tidak dapat dihilangkan dan sudah menjadi budaya bagi masyarakat Gampong Paloh Lada.

2. Perbedaan tradisi jeulamee di Pasee Utara dengan tradisi jeulamee di wilayah Pasee lainnya yaitu penetapan mahar mas kawin (jeunamee) ditentukan oleh kedua belah pihak tanpa memberatkan bagi pihak lelaki, namun bagi keluarga yang mempunyai kehidupan sosial yang tinggi, maka penetapan jeunamee ditentukan oleh keluarga pihak perempuan. 
3. Upaya dalam mempertinggi jeulamee wilayah Pasee Utara dijadikan sebagai salah satu adat yang telah diwariskan turun temurun dalam menjaga ikatan dan solidaritas yang kuat di masyarakat, sehingga derajat wanita dalam sosial masyarakat tidak diremehkan, namun bagi keluarga perempuan yang status sosialnya sederhana, maka jeulamee yang diminta tidak memberatkan pihak kaum lelaki yang melamarnya. Dalam hal ini tidak adanya sanksi bila kesepakatan tidak terpenuhi, namun pernikahan bisa jadi dibatalkan karena keadaan yang tidak memungkinkan. 


\section{Daftar Pustaka}

Abdullah, Ilham. 2010. Kado Buat Mempelai. Yogyakarta: Absolut.

Abidin, Abdurrahman. 2009. Kompilasi Hukum Islam Di Indonesia. Jakarta: Akademi Pressindo.

Alfian. 2005. Persepsi Masyarakat Tentang Kebudayaan. Jakarta: PT Gramedia.

Arikunto, Suharsimi. 2002. Prosedur Penelitian : Suatu Pendekatan Praktek. Jakarta: Rineka Cipta.

BPS. 2014. Aceh Dalam Angka. Banda Aceh: Bappeda Aceh.

Cut Intan Elly Arby. 2005. Tata Rias dan Upacara Adat Perkawinan Aceh. Banda Aceh: Yayasan Meukuta Alam.

Dedi Rohayana. 2008. Ilmu Kaidah-kaidah Hukum Islam. Jakarta: Gaya Media Pratama.

Faridl, Miftah. 2009. Masalah Nikah dan Keluarga. Jakarta: Gema Insan Press.

Fina, Musfiroh. 2015. Tinjauan Hukum Islam Terhadap Praktek Pemberian Peminangan yang Dijadikan Mahar (Studi Kasus di Desa Sriwulan Kecamatan Limbangan Kabupaten Kendal). Skripsi. Fakultas Syariah. Program Studi Hukum Islam. Universitas Islam Negeri Walisongo. Semarang.

Hadikusuma, Hilman. 2005. Hukum Perkawinan Adat. Bandung: PT. Citra Aditya Bakti.

Haviland, William. 2008. Antropologi edisi ke empat jilid 2. Bandung: Presco.

Ihroni, 2010. Antropologi dan Hukum. Jakarta: Yayasan Obor Indonesia.

Koentjaningrat. 2002. Pengantar Ilmu Antropologi. Jakarta: Rineka Cipta.

Moleong, Lexy A. 2005. Metodologi Penelitian Kualitatif. Bandung: Remaja Rosdakarya.

Nurhilaliati. 2007. Perempuan dan Mahar. IAIN Mataram Press: Mataram.

Nurul Hikmah. 2011. Implementasi Pemberian Mahar Pada Masyarakat Suku Bugis (Studi Kasus Di Kelurahan Kalibaru Kecamatan Cilincing Jakarta Utara). Skripsi. Fakultas Syariah Program Studi Hukum Islam. Universitas Islam Negeri Syarif Hidayatullah. Jakarta.

Pemerintah Kabupaten Aceh Utara. 2014. Laporan Akuntabilitas Kinerja Instansi Pemerintah (LAKIP). Aceh Utara. Provinsi Aceh. 
Aceh Anthropological Journal, Vol. 4, No. 2, hlm: 215-236, Oktober 2020

Salaeman, Munandar. 2008. Ilmu Budaya dasar Suatu Pengantar. PT. Eresco. Bandung.

Tebba, Sudirman. 2003. Sosiologi Hukum Islam. UII Press. Yogyakarta. 